\title{
Cancer-related radiation therapy in early childhood leading to root abnormality in multiple permanent teeth
}

\author{
Morankar Rahul @ (, Mohammad Atif, Nitesh Tewari, Vijay Mathur
}

Division of Pedodontics and Preventive Dentistry, Center for Dental Education and Research, AllMS, New Delhi, Delhi, India

\section{Correspondence to} Dr Morankar Rahul; captainrahul88@gmail.com

Accepted 12 August 2021

Check for updates

(c) BMJ Publishing Group Limited 2021. No commercial re-use. See rights and permissions. Published by BMJ.

To cite: Rahul M, Atif M, Tewari N, et al. BMJ Case Rep 2021;14:e244770. doi:10.1136/bcr-2021244770

\section{DESCRIPTION}

Dental sequelae to anticancer therapy (ACT), which includes chemotherapy and irradiation, are irreversible in growing individuals. A triad of age of the child, ACT (its form and duration), and the stage of development govern the severity of developmental dental abnormalities. Since, it is known that ACT targets the cells in an active state of the cell cycle, the regions of the jaw and tooth development get adversely affected.

This is a case of a 16-year-old boy who reported to the outpatient department of division of paediatric dentistry with a report of the discoloured teeth. Medical history revealed that the patient has been treated at the cancer hospital in All India Institute of Medical Sciences, New Delhi, and is currently under the follow-up without any recurrence. Medical history revealed the child had a malignant round cell thalamic tumour diagnosed at the age of 5 years. When the treating oncologist was consulted, it was revealed that the child had received chemotherapy that was initiated at the age of 5 years and persisted till 7 years of age. Therapy includes a combination of anticancer drugs under Vincristine, Actinomycin-D, Cyclophosphamide (VAC)/Ifosfamide, Etoposide (IE) protocol (named after drugs used) in six cycles, repeated every 6 weeks and spread over a span of 48 weeks. Doses were given according to the body surface area of the patient with a cumulative dose of vincristine $(18 \mathrm{mg} /$ $\left.\mathrm{m}^{2}\right)$, doxorubicin $\left(375 \mathrm{mg} / \mathrm{m}^{2}\right)$, actinomycin-D $(5 \mathrm{mg} /$ $\left.\mathrm{m}^{2}\right)$, cyclophosphamide $\left(10800 \mathrm{mg} / \mathrm{m}^{2}\right)$, ifosfamide $\left(72000 \mathrm{mg} / \mathrm{m}^{2}\right)$ and etoposide $\left(4000 \mathrm{mg} / \mathrm{m}^{2}\right)$. The child also received radiation therapy commencing at the age of 5 years with a total dose of $55.9 \mathrm{~Gy}$, comprising of whole brain radiation and spinal radiation in 35 fractions followed by boost radiation to the primary tumour (thalamic region) in 20 fractions.

There was no abnormality evident on extraoral examination. Intraoral examination revealed that the child had permanent dentition with generalised stain deposits with multiple teeth and a grade 1 mobility with mandibular incisors. Oral hygiene was fair with generalised mild gingival inflammation. Pit and fissure caries was present with left maxillary and mandibular permanent first molars. Orthopantomogram revealed arrested root development with multiple teeth (figure 1). The effects were most pronounced in mandibular incisors, which had minimal root area to support the overlying crown. The mandibular premolar and canine showed arrested root development with short V-shaped roots, whereas the mandibular first molars showed premature apical root closure.

There is strong evidence that supports the association between childhood cancer-related chemoirradiation and developmental dental abnormalities. ${ }^{12}$ Radiation to the teeth buds at their early stage of development has been associated with dental abnormalities, such as tooth agenesis, root shortening, early apical closure, coronal hypocalcification and microdontia. ${ }^{3}{ }^{4}$ Children who received local radiation are at increased risk of developmental dental abnormalities later in life. ${ }^{5-7}$ It has been also observed that the children who had received more than $24 \mathrm{~Gy}$ of cranial radiation at age less than 5 years are more prone to the dental defects. ${ }^{8}$ Development of tooth starts at 4 months of intrauterine life and continues till 14 years of age. The primary tooth germs in the postnatal period, are mostly at the stage of crown calcification and initiation of root formation. The development of the first permanent tooth germ starts at the time of birth that comprises of various stages, initiation, proliferation, histodifferentiation, morphodifferentiation and apposition, marked by the increased cellular activity of cell lines. ${ }^{9}$ Periodic examinations post radiation therapy is essential to provide comprehensive oral healthcare. Dental treatment may require a multidisciplinary approach, involving a variety of dental specialists to address the treatment needs of each individual. There is no evidence regarding the benefits of fluoride in prevention of tooth-related abnormalities, although, caries preventive effect is still crucial considering higher tendency of dental caries in hypoplastic teeth. Dental implants remain the mainstay in the management of cases with tooth agenesis.

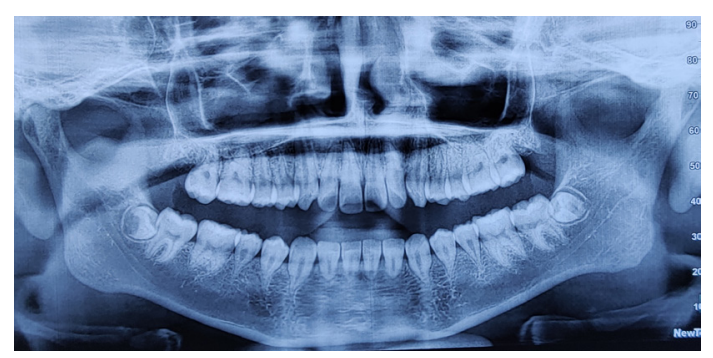

Figure 1 Orthopantomogram showing arrested root growth in multiple teeth. The effects range from premature apical closure in mandibular first molars to almost complete root agenesis with mandibular incisors. 
The survivors may also experience salivary gland dysfunction/hypofunction or xerostomia along with the abnormalities of tooth development. ${ }^{10}$ This can lead to oral discomfort, difficulty in speech, dysphagia and viscous saliva. The xerostomia further can lead to tooth demineralisation, dental caries and periodontal disease. ${ }^{11}$ These consequences can be managed by patient education, prevention, symptomatic therapy and use of systemic and topical salivary stimulants. Radiation therapy directed at/near the mouth can affect the process of enamel and dentin formation. It has been found that the teeth, which are located even along the edges of a radiation beam exposure, can receive up to the $45 \%$ of the administered dose of radiation. ${ }^{8}$ In the present case, the tooth abnormality has been observed in the mandibular dentition and the effects were more pronounced in the incisor region, indicating the consequences of directed radiation rather than a chemotherapeutic drug. Radiation when directed at distant areas of the body has found to have minimal effect on dental development. The same is evident in the present case, with unaffected maxillary dentition and lesser affected mandibular posterior teeth in spite of severe root stunting in mandibular incisor region. Whole brain radiation therapy along with boost and spinal irradiation could have been the reason for

\section{Patient's perspective}

We visited the dental outpatient department for the routine dental examination of our child. However, the doctors there told us that the anticancer therapy has significantly affected the growth of teeth. These effects are irreversible and our child needs to be careful to avoid trauma or biting hard with these teeth as there is a little root to support.

\section{Learning points}

- Young age of the patient, site of radiation beam, and dose received during the cancer-related radiation therapy are the principal determinants of severity of oral consequences.

- An emphasis should also be given to the structures via which the radiation is passing, particularly in children, as it can lead to adverse effects on developing structures localised in that area.

- The use of site-specific irradiation should be encouraged to reduce its effect over the healthy tissues. The mandibular and maxillary regions should be considered as organs at risk when radiotherapy is delivered to a child to minimise their irradiation.

- An appropriate protocol for the regular visits to the dentist should be promoted to reduce the effect of developmental dental anomalies on day-to-day functional activity and patients should be counselled to maintain oral health, thereby improving their oral health-related quality of life. the affected tooth development present in the midline. Considering the finding that maxillary teeth were relatively unaffected, the likely cause of stunted root development in the mandibular incisor could be their proximity to spinal irradiation. The ameloblasts are very sensitive cells and a dose as low as $10 \mathrm{~Gy}$ can lead to their permanent damage. ${ }^{12}$ The goal of any radiation therapy is to kill the tumour cells with minimal damage to the adjacent normal tissues. However, the cells/tissue, which are along the line of radiation beam or near the implanted radioisotope, experience adverse reaction and these effects may be noted bilaterally even if the tumour is unilateral. ${ }^{13}$

Acknowledgements We thank Mr Ashish Jena for his technical support in this publication.

Contributors MR was involved in the concept, design, review of literature and preparation of the manuscript. VM and NT were involved in the review of literature, preparation and critical revision of the manuscript. MA was involved in patient care, preparation and revision of the manuscript.

Funding The authors have not declared a specific grant for this research from any funding agency in the public, commercial or not-for-profit sectors.

Competing interests None declared.

Patient consent for publication Parents/Guardian consent obtained.

Provenance and peer review Not commissioned; externally peer-reviewed.

ORCID iD

Morankar Rahul http://orcid.org/0000-0002-2924-8857

\section{REFERENCES}

1 Rosenberg SW, Kolodney H, Wong GY, et al. Altered dental root development in longterm survivors of pediatric acute lymphoblastic leukemia. A review of 17 cases. Cancer 1987;59:1640-8

2 Weyman J. The effect of irradiation on developing teeth. Oral Surg Oral Med Oral Pathol 1968;25:623-9.

3 Effinger KE, Migliorati CA, Hudson MM, et al. Oral and dental late effects in survivors of childhood cancer: a children's Oncology Group report. Support Care Cancer 2014;22:2009-19.

4 Nemeth 0 , Hermann P, Kivovics P, et al. Long-term effects of chemotherapy on dental status of children cancer survivors. Pediatr Hematol Oncol 2013;30:208-15.

5 Jaffe $\mathrm{N}$, Toth BB, Hoar RE, et al. Dental and maxillofacial abnormalities in long-term survivors of childhood cancer: effects of treatment with chemotherapy and radiation to the head and neck. Pediatrics 1984;73:816-23.

6 Laverdière $\mathrm{C}$, Cheung N-KV, Kushner BH, et al. Long-term complications in survivors of advanced stage neuroblastoma. Pediatr Blood Cancer 2005;45:324-32.

7 McGinnis JP, Hopkins KP, Thompson El, et al. Tooth root growth impairment after mantle radiation in long-term survivors of Hodgkin's disease. J Am Dent Assoc 1985;111:584-8

8 Sonis AL, Tarbell N, Valachovic RW, et al. Dentofacial development in long-term survivors of acute lymphoblastic leukemia. A comparison of three treatment modalities. Cancer 1990;66:2645-52.

9 Logan WHG, Keonfeld R. Development of the human jaws and surrounding structures from birth to age fifteen. Am Den A J 1935;20:379-424.

10 Jensen SB, Pedersen AML, Vissink A, et al. A systematic review of salivary gland hypofunction and xerostomia induced by cancer therapies: prevalence, severity and impact on quality of life. Support Care Cancer 2010;18:1039-60.

11 Pinna R, Campus G, Cumbo E, et al. Xerostomia induced by radiotherapy: an overview of the physiopathology, clinical evidence, and management of the oral damage. Ther Clin Risk Manag 2015;11:171-88.

12 Kaste SC, Goodman P, Leisenring W, et al. Impact of radiation and chemotherapy on risk of dental abnormalities: a report from the childhood cancer Survivor study. Cancer 2009;115:5817-27

13 Goho C. Chemoradiation therapy: effect on dental development. Pediatr Dent 1993;15:6-12 
Copyright 2021 BMJ Publishing Group. All rights reserved. For permission to reuse any of this content visit https://www.bmj.com/company/products-services/rights-and-licensing/permissions/

BMJ Case Report Fellows may re-use this article for personal use and teaching without any further permission.

Become a Fellow of BMJ Case Reports today and you can:

- Submit as many cases as you like

- Enjoy fast sympathetic peer review and rapid publication of accepted articles

Access all the published articles

Re-use any of the published material for personal use and teaching without further permission

Customer Service

If you have any further queries about your subscription, please contact our customer services team on +44 (0) 2071111105 or via email at support@bmj.com.

Visit casereports.bmj.com for more articles like this and to become a Fellow 